\title{
SURVEY AND SEASONAL ABUNDANCE OF LEAFHOPPERS INFESTING SOME SOLANACEOUS AND CRUCIFEROUS CROPS.
}

\author{
R.E.M. Omar ${ }^{1}$; A.M. Hegab $^{2}$; El-Bery, A. A. ${ }^{1}$ and M. S. Hashem, ${ }^{3}$ \\ 1. Plant Prot. Dept., Faculty Agric., Benha Univ., Benha, Egypt. \\ 2. Plant Prot. Dept., Faculty Agric., Zagazig Univ., Zagazig, Egypt. \\ 3. Plant Protection Institute, Dokii, Giza, Egypt.
}

\begin{abstract}
A survey and seasonal abundance of leafhopper species on certain selanaceous and cruciferous vegetable plants in Sharkia, Egypt were studied by using sweeping net and sticky board traps throughout 2002/2003 and 2003/2004 seasons. The obtained results showed that the dominant leafhopper species on pepper plants were Empoasca decipiens (Paoli), E. decedens (Paoli), Cicadulina chinai (Ghauri) and Circulifer tenellus (Baker). On eggplant E. decipiens, E. decedens, C. chinai and E. lybica (De Barg). On cabbage and cauliflower plants, E. decipiens, E. decedens and Balclutha hortensis (Lindb.) were found. The seasonal abundance of the dominant leafhopper species can be summarized as follows: The population density of $E$. decipiens were recorded two peaks at the $3^{\text {rd }}$ week of July and the $3^{\text {rd }}$ week of September, respectively on pepper and eggplant, while on cabbage and cauliflower plants two peaks were noticed at $4^{\text {th }}$ week of October and at the end of January, respectively. On the other hand, E. decedens had one peak occurred at the $2^{\text {nd }}$ week of August on eggplant plants and at the $2^{\text {nd }}$ week of November on cabbage and cauliflower plants, while on pepper plant tow peaks were showed at the $3^{\text {rd }}$ week of July and at the $3^{\text {rd }}$ week of September. Population of B. hortensis recorded one peak with high population density at the $2^{\text {nd }}$ week of October on cabbage and cauliflower plants. Population density of C. chinai recorded only one peak on pepper plants at the $3^{\text {rd }}$ week of September. On the other hand, population of E. lybica on eggplant showed two peaks at the $3^{\text {rd }}$ week of July and at the $3^{\text {rd }}$ week of September.
\end{abstract}

Keywords: Sollanacous, Cruciferous Plants, Seasonal abundance, leafhopper.

\section{INTRODUCTION}

Leafhoppers are serious insect pests infesting solanaceous and cruciferous plants. Several investigators recorded the role of some leafhopper species in transmitting the pathogens of plant diseases (Hegab, et al. 1989 a, b \& 2005). The faun of these insects in different plantation either with vegetables or fruit trees were studied in Egypt (Helal, et al., 1996 \& El-Gindy, 2002). The aim of the present work is to survey the leafhoppers on certain solanaceous plants (pepper and eggplant) and 
cruciferous plants (cabbage and cauliflower) as well as to clear the seasonal abundance of the dominant species during 2002/2003 and 2003/2004 seasons in Minia El-Kamh, district, Sharkia Governorate.

\section{MATERIALS AND METHODS}

An area about $1 / 2$ feddan divided into two equal plots particularized for winter plantation (cabbage \& cauliflower plants) and summer plantation (pepper and eggplants). All the experimental plots received the normal agricultural practices Sampling with weekly intervals started 4 weeks from sowing date.

Sampling started when the age of the Pepper, Eggplant, Cabbage and Cauliflower plants reached about 4 weeks and continued at weekly intervals throughout, summer and winter plantation at Minia El-Kamh, district, Sharkia Governorate in 2002/2003, 2003/2004 seasons. The following two procedures of sampling were used: (1) sweeping net, of $30 \mathrm{~cm}$ diameter and $75 \mathrm{~cm}$ deep and each sample consisted of 200 single strokes taken from both diagonal directions of the field. (2) The yellow sticky board traps $20 \times 20$ $\mathrm{cm}$ were hanged on wood rods in the field. The height of the wood rods varied according to the height of the plants throughout the period of samples. The collected leafhopper specimens, sorted into species. Recorded of meteorological station at Zagazig city to represent the condition prevailing in the field during the period of investigation.

\section{RESULTS AND DISCUSSION}

\section{1- Survey of leafhopper species infesting certain solanaceous and cruciferous plants:}

Survey of leafhopper species infesting certain solanaceous and cruciferous plants (pepper, eggplant, cabbage \& cauliflower) are shown in Table (1).

The data presented in Table (1) show the incidence of the leafhopper species belonging to family Cicadellidae on pepper, eggplant, cabbage \& cauliflower plants in Minia El-Kamh, district, Sharkia Governorate. These species are as follows:

i) On pepper plants (Capsicum anuum L.):

Four leafhopper species were collected and arranged descendingily according to their abundance on pepper plants as follows Empoasca decipiens (Paoli), E. decedens (Paoli), Cicadulina chinai (Ghauri) and Circulifer tenellus (Baker) during 2002/2003 and 2003/2004 respectively. Empoasca decipiens (Paoli) was the most abundant leafhopper species on pepper plants during the two investigation seasons.

ii) On eggplant (Solanum melongena L.):

Data obtained revealed that the following leafhopper species were found on eggplant plants: E. lybica (de Berg), E. decipiens (Paoli), E. decedens (Paoli) and $C$. chinai (Ghauri) in the two successive seasons 2002/2003 and 2003/2004 respectively. 
Empoasca lybica (de Berg) was the most abundant leafhoppers species on eggplant plants during the summer plantations of 2002 and 2003 seasons.

These results agree with the findings of El-Blook (1976), Hegab et al. (1989 a \& b) and Hamdi and Emam (1994).

iii) On cabbage plants (Brassica oleracea var. capitata $\mathrm{L}_{\text {. }}$ ):

The data presented in Table (1) show the total number of the three leafhoppers species collected by the two different techniques. Leafhopper species were collected and arranged descendingly according to their abundance: Balclutha hortensis (Lindb), E. decipiens and E. decedens.

iv) On cauliflower plants (Brassica oleracea var. botrytis L.):

Cauliflower plants were attacked by the following leafhopper species: $B$. hortensis, E. decipiens and E. decedens. B. hortensis was the most abundant species on cabbage and cauliflower plants during 2002/2003 and 2003/2004 seasons. Concerning the efficiency of the two aforementioned methods of surveying, it appears that the use of sweeping nets was the most efficient. The total numbers of all species collected by each of the two methods were $22289 \& 20605$ and $12670 \& 10622$ individuals, respectively in the two investigation seasons.

Table (1):Total number of leafhopper species collected by different techniques from certain solananceous and cruciferous plants in Minia El-Kamh district, Sharkia Governorate collected during 2002/2003 and 2003/2004 seasons.

\begin{tabular}{|c|c|c|c|c|c|}
\hline \multirow{3}{*}{$\begin{array}{l}\text { Leafhopper } \\
\text { species }\end{array}$} & \multirow{3}{*}{ Host plants } & \multicolumn{4}{|c|}{ Total number of leafhoppers/sample } \\
\hline & & \multicolumn{2}{|c|}{$2002 / 2003$} & \multicolumn{2}{|c|}{$2003 / 2004$} \\
\hline & & S.N. & Y.S.B.T. & S.N. & Y.S.B.T. \\
\hline \multirow{4}{*}{ Empoasca decipiens) } & Pepper & 1864 & 1089 & 1541 & 890 \\
\hline & Eggplant & 2766 & 1449 & 2451 & 1390 \\
\hline & Cabbage & 933 & 486 & 1126 & 594 \\
\hline & Cauliflower & 847 & 530 & 1074 & 614 \\
\hline \multirow{4}{*}{ Empoasca decedens } & Pepper & 1226 & 726 & 1051 & 597 \\
\hline & Eggplant & 2310 & 1376 & 2132 & 1295 \\
\hline & Cabbage & 588 & 256 & 594 & 288 \\
\hline & Cauliflower & 479 & 145 & 531 & 161 \\
\hline \multirow{2}{*}{ Balchutha hortensis } & Cabbage & 1135 & 543 & 1267 & 680 \\
\hline & Cauliflower & 1059 & 631 & 1513 & 729 \\
\hline \multirow{2}{*}{ Cicadulina chinai } & Pepper & 1044 & 545 & 976 & 402 \\
\hline & Eggplant & 1893 & 895 & 1659 & 697 \\
\hline Empoasca lybica & Eggplant & 5162 & 3504 & 3892 & 1904 \\
\hline Circulifer tenellus & Pepper & 983 & 495 & 798 & 381 \\
\hline \multicolumn{2}{|c|}{ Total } & 22289 & 12670 & 20605 & 10622 \\
\hline
\end{tabular}


These results agreed with the findings by Hegab et al. (1989 a, b), El-Gendy (2002) and disagreed with Hemeida (1981) who maintained that, only E. decipiens infested solanaceous vegetable plants at Giza region.

\section{2- Seasonal abundance of the dominant leafhopper species infesting some solanaceous and cruciferous plants:}

The following discussion on the population density of the dominant leafhopper species are based on the records of the sweeping nets technique. In all cases the other technique (yellow sticky board traps) showed trends similar to those of the sweeping net.

\section{i) On pepper plants:}

a) Empoasca decipiens (Paoli):

Empoasca decipiens was the most abundant leafhopper species on pepper plants during 2002 and 2003 seasons.

Data presented in Figs. (1\&2) show that the first observation of leafhoppers occurred at the end of May. The initial number of E. decipiens adult was noticed on the $4^{\text {th }}$ week of May at $26.77^{\circ} \mathrm{C}, 26.48^{\circ} \mathrm{C}$ with a mean of $54.50 \%$ and $49.00 \%$ R.H for both seasons, respectively. According to the population density of E. decipiens individuals on pepper plants two peaks which occurred during the two seasons of investigation. The first one was recorded at the $3^{\text {rd }}$ week of July with a mean number of 82 and 54 adults/200 strokes in 2002 and 2003 seasons, respectively at $29.91^{\circ} \mathrm{C}, 28.48^{\circ} \mathrm{C}$ with $62.29 \%$ and $61.28 \%$ R.H for the aforementioned seasons. While the second peak was obtained at the $3^{\text {rd }}$ week of September with a mean numbers of 33 and 30 adults/sample at mean temperatures of $27.03^{\circ} \mathrm{C}, 27.41^{\circ} \mathrm{C}$ with $54.86 \%$ and $58.57 \%$ R.H for the two successive seasons, respectively.

\section{b) Empoasca decedens (Paoli):}

The total number of $E$. decedens individuals collected from pepper plants during 2002 and 2003 seasons are illustrated graphically in Figs. (1\&2). The initial infestation by $E$. decedens were recorded at the $4^{\text {th }}$ week of May.

According to the population density of $E$. decedens adult recorded two peaks on pepper plant, during the two seasons of 2002/2003, 2003/2004. The first one was observed at the $3^{\text {rd }}$ week of July with a mean numbers of 36 and 32 adult/sample at mean temperature of $29.91^{\circ} \mathrm{C}, 28.48^{\circ} \mathrm{C}$ with $62.29 \%$ and $61.28 \%$ R.H for the two experimental seasons. The second peak was obtained in the $3^{\text {rd }}$ week of September with a total numbers of 27 and 19 adults/ sample at mean temperature of $27.03^{\circ} \mathrm{C}$, $27.41^{\circ} \mathrm{C}$ with $54.86 \%$ and $58.57 \%$ R.H for two seasons respectively.

Then the numbers of leafhopper decreased until reached the minimal numbers at the $2^{\text {nd }}$ week of October with a total numbers of 4 and 3 adults/sample at mean temperature of $25.55^{\circ} \mathrm{C}$ and $24.74^{\circ} \mathrm{C}$ and $61.71 \%$ and $62.14 \%$ R.H during the two successive seasons. 
$\rightarrow-$ R.H. \% $\rightarrow$ Temp.
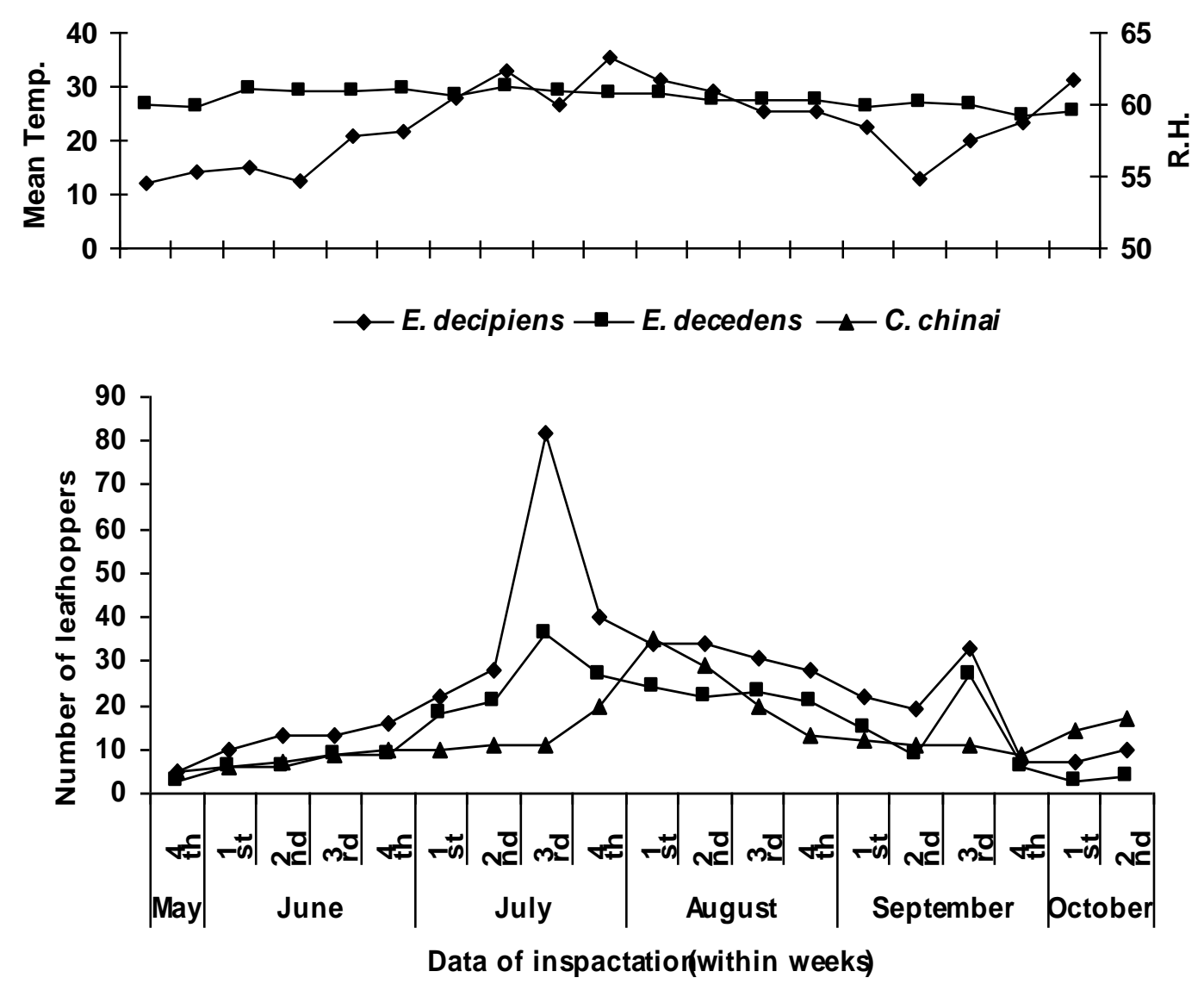

Fig. (1): Seasonal abundance of leafhoppers E. decipiens, E. decedens and C. chinai infesting pepper plants collected by sweeping net at Minia El-Kamh district, Sharkia Governorate during 2002/2003.

\section{c) Cicaduline chinai (Ghauri):}

The first appearance of $C$. chinai individuals was pointed out at the end of May for both 2002 and 2003 seasons, at $26.77^{\circ} \mathrm{C}, 26.48^{\circ} \mathrm{C}$ with $54.50 \%, 49.00 \%$ R.H for the two seasons, respectively as shown in Figures $(1 \& 2)$.

The initial numbers per a sample (200 strokes) were 5 and 3 individuals in the two seasons, respectively. According to the abundance of $C$. chinai (Ghauri) individuals on pepper plants, there are only one peak recorded at the $1^{\text {st }}$ of August with a total number of 35 and 37 adult/sample for 2002 and 2003 seasons, respectively at $28.90^{\circ} \mathrm{C}, 28.03^{\circ} \mathrm{C}$ with $63.29 \%, 61.29 \%$ R.H for the two seasons, respectively. 

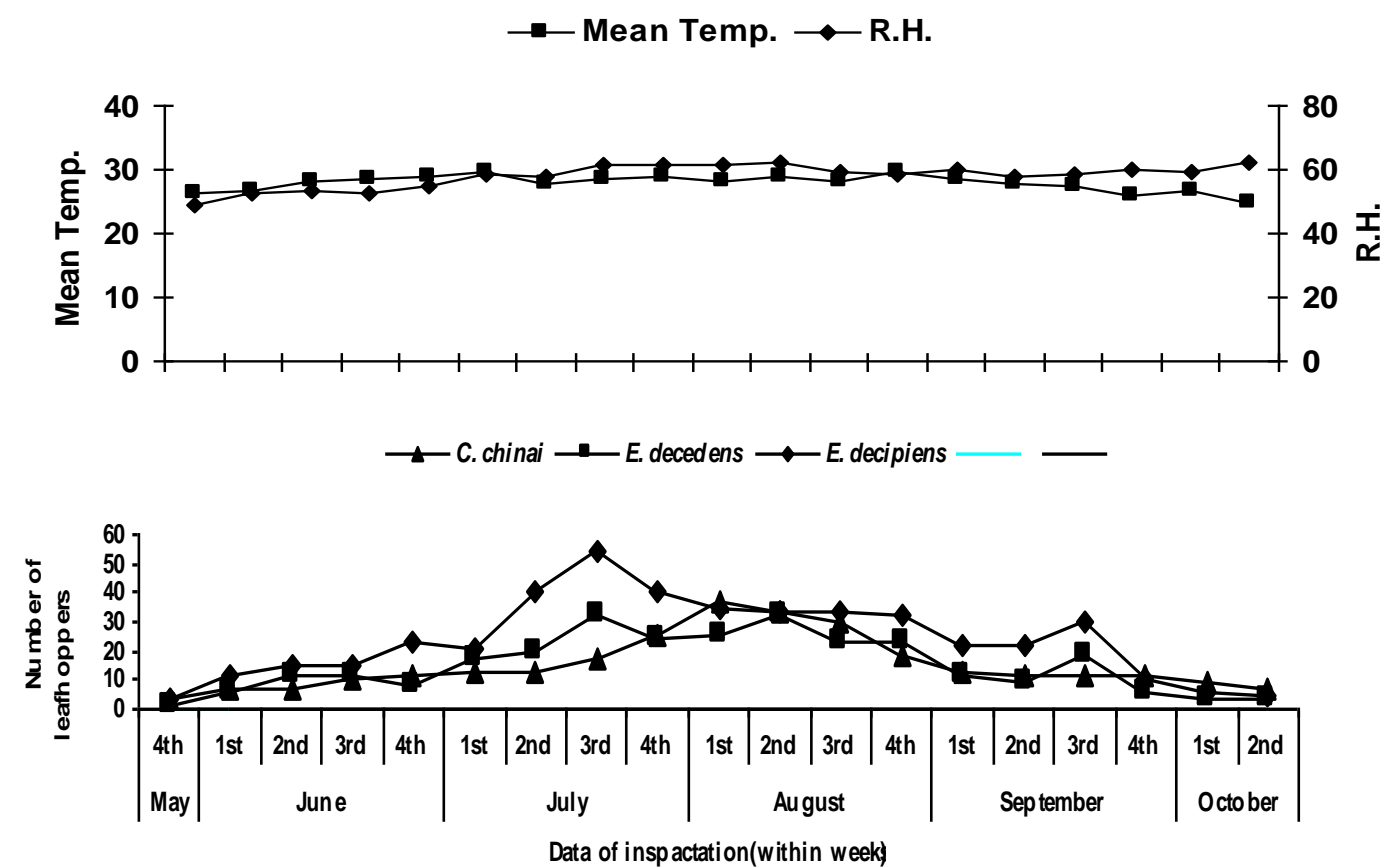

Fig. (2): Seasonal abundance of leafhoppers E. decipiens, E. decedens and C. chinai infesting pepper plants collected by sweeping net at Minia El-Kamh district, Sharkia Governorate during 2003/2004 season.

\section{ii) Eggplant plants:}

a) Empoasca decipiens (Paoli)

The total number of leafhoppers infesting eggplant plants during the period from the $4^{\text {th }}$ week of May to the $2^{\text {nd }}$ week of October are illustrated graphically in Figures( $3 \& 4)$. According to population fluctuation of E. decedens adult on eggplants plants during summer plantation, two peaks were obtained. The first one was recorded at the $3^{\text {rd }}$ week of July with a total number of 69 and 45 adult/sample in 2002 and 2003 seasons, respectively at $29.91^{\circ} \mathrm{C}, 28.48^{\circ} \mathrm{C}$ and $62.29 \%, 61.28 \%$ R.H for the two seasons, respectively. The second peak was noticed at the $3^{\text {rd }}$ week of September with mean numbers of 78 and 60 adults/sample at mean temperatures of $27.03{ }^{\circ} \mathrm{C}, 27.41^{\circ} \mathrm{C}$ with $54.86 \%$ and $58.57 \%$ R.H for the two seasons, respectively.

\section{b) Empoasca decedens (Paoli).}

The total numbers of $E$. decedens leafhopper collected from eggplant plants during 2002 and 2003 seasons are illustrated graphically in Figures (3\&4). The initial occurrence of E. decedens on eggplant plants were 9 and 3 adult /sample at the $4^{\text {th }}$ week of May in 2002 and 2003 seasons, respectively with a mean temperature of $26.77^{\circ} \mathrm{C}, 26.48^{\circ} \mathrm{C}$ and $54.50 \%, 49.00 \%$ R.H for both seasons, respectively. Population density of $E$. decedens tended to increase until reached its first peak at the $2^{\text {nd }}$ week of August with a total number of 57 and 69 adult/sample in 2002 and 2003 seasons, respectively at $28.69^{\circ} \mathrm{C}, 28.84^{\circ} \mathrm{C}$ with $61.71 \%, 61.86 \%$ R.H for the two seasons, 
respectively. After this peak E. decedens numbers tended to decline until reached its minimal number in $2^{\text {nd }}$ week of October with a total numbers 20 and $7 E$. decedens/sample in 2002 and 2003 seasons, respectively when the mean temperature were $25.55^{\circ} \mathrm{C}$ and $24.74^{\circ} \mathrm{C}$ and R.H were $61.71 \%$ and $62.14 \%$ for both seasons, respectively.

\section{c) Cicadulina chinai (Ghauri).}

The adults $C$. chinai started to appear in both seasons from about the $3^{\text {rd }}$ and $2^{\text {nd }}$ weak of June for 2002 and 2003 seasons, respectively at $29.10^{\circ} \mathrm{C}, 28.05^{\circ} \mathrm{C}$ with $54.71 \%, 53.57 \%$ R.H for the two seasons respectively. The initial numbers/sample (200 strokes) were 15 and 6 individuals in the two seasons, respectively. According to the abundance of $C$. chinai individuals on eggplant plants, only one peak was recorded at the $3^{\text {rd }}$ of September with a total number of 67 and 45 adult/ sample for at $27.03^{\circ} \mathrm{C}, 27.41^{\circ} \mathrm{C}$ with $54.86 \%, 58.57 \%$ R.H, 2002 and 2003 seasons respectively. The number of $C$. chinai tended to decline until reached its minimal at the $2^{\text {nd }}$ week of October with a total number of 10 and 15 adult/sample at a mean temperature of $25.55^{\circ} \mathrm{C}, 24.74^{\circ} \mathrm{C}$ with $61.71 \%, 62.14 \%$ R.H for two seasons, respectively.

\section{d) Empoasca Lybica (de Berg.).}

The first collections of E. lybica adults were noticed at the $4^{\text {th }}$ week of May (15 and 8 adult/sample) at $26.77^{\circ} \mathrm{C}, 26.48^{\circ} \mathrm{C}$ with a mean of $54.50 \%$ and $49.00 \%$ R.H for both seasons respectively.

According to the abundance of E. lybica adults on eggplant plants appeared two peaks during the two seasons of investigation. The first one was recorded at the $3^{\text {rd }}$ week of July with a mean number of 108 and 84 adults/sample in 2002 and 2003 seasons, respectively at $29.91^{\circ} \mathrm{C} 28.48^{\circ} \mathrm{C}$ with $62.29 \%$ and $61.28 \%$ R.H for two successive seasons. The second peak was obtained at the $3^{\text {rd }}$ week of September with mean numbers of 100 and 90 adults/sample at mean temperature of $27.03^{\circ} \mathrm{C}, 27.41^{\circ} \mathrm{C}$ with $54.86 \%$ and $58.57 \%$ R.H for the two seasons, respectively. Regarding the weekly counts of E. lybica on eggplant plants, it clear that this species was more abundant during 2002 than 2003 seasons. These results agree with those obtained by El-Kady et al. (1973), Herakly (1974), Metwally (1976), Hegab et al. (1989a,b), Hamdi (1992) and Hamdi and Emam (1994).

\section{iii) On cabbage plants.}

\section{a) Empoasca decipiens (Paoli):}

The data obtained in Figures (5\&6) indicated two peaks representing high population densities for E. decipiens. The first one occurred on the $4^{\text {th }}$ week of October with a total numbers of 51 and 63 adults/sample in 2002/2003 and 2003/2004 seasons, respectively at a mean temperature of $22.92^{\circ} \mathrm{C}, 26.95^{\circ} \mathrm{C}$ with $60.40 \%, 59.60 \%$ R.H in the two investigation seasons, respectively. The second peak was noticed in the end week of January with total numbers of 11 and 21 adults/sample in the two seasons 

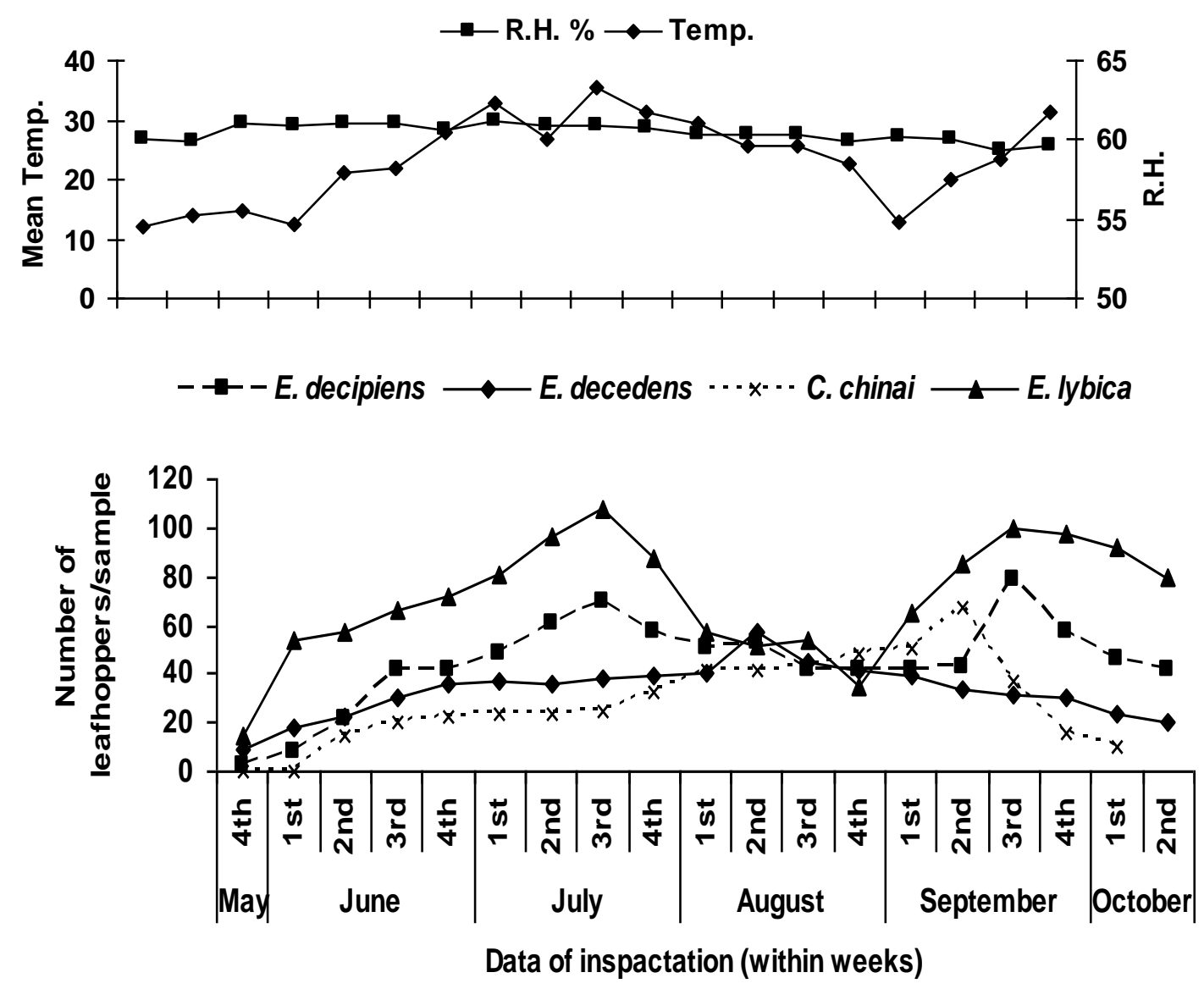

Fig. (3): Seasonal abundance of leafhoppers E. decipiens, E. decedens, C. chinai and E. lybica infesting Eggplant plants collected by sweeping net at Minia El-Kamh district, Sharkia Governorate during 2002 / 2003 season.

respectively at a mean temperature of $14.71^{\circ} \mathrm{C}, 14.84^{\circ} \mathrm{C}$ with $56.40 \%, 61.10 \%$ R.H for the two seasons, respectively.

It is worth to mention that a low peak of population density was observed at the $1^{\text {st }}$ week of March, 2003/2004 with a total number 15 adults/sample at a mean temperatures of $20.43^{\circ} \mathrm{C}$ with $66.14 \% \mathrm{R}$.H. This differences may be due to the variations of environmental conditions prevailing during execution of these experiments.

\section{b) Empoasca decedens (Paoli).}

Figures (5\&6), showed that the first samples were collected in the $1^{\text {st }}$ week of October and the initial occurrence of leafhopper in cabbage plant were 3 and 6 adult/sample in 2002/2003 and 2003/2004 seasons, with a mean temperature of $24.79^{\circ} \mathrm{C}, 26.53^{\circ} \mathrm{C}$ with $58.71 \%, 59.57 \%$ R.H for both seasons, respectively. 

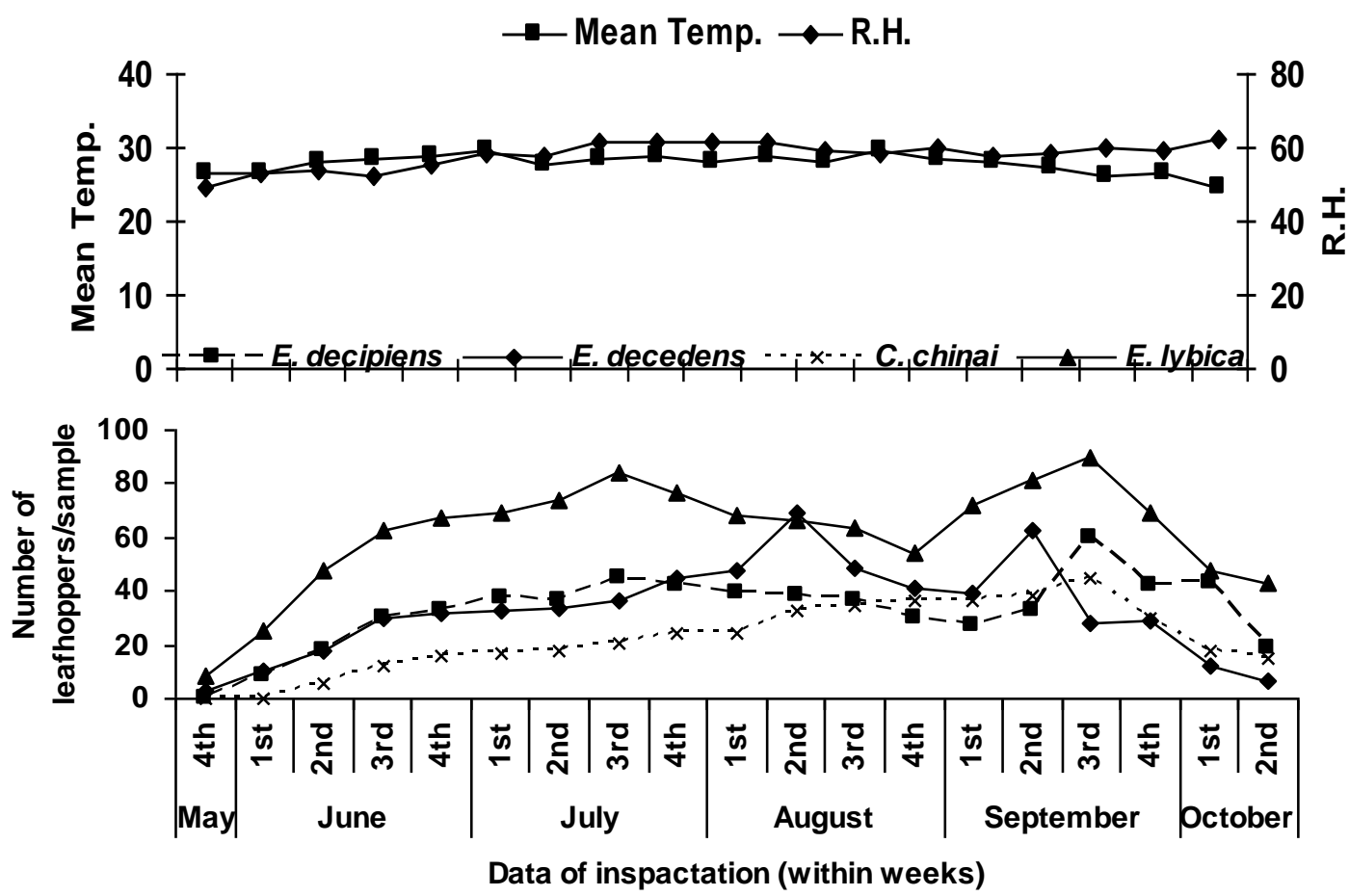

Fig. (4): Seasonal abundance of leafhoppers E. decipiens, E. decedens, C. chinai and E. lybica infesting Eggplant plants collected by sweeping net at Minia El-Kamh district, Sharkia Governorate during 2003/2004 season.

Figures (5\&6) indicate that the mean number of leafhoppers on cabbage plants tended to increase until reached its first peak at the $2^{\text {nd }}$ week of November showing total numbers of 22 and 24 adult/sample at $12.55^{\circ} \mathrm{C}$ and $22.27^{\circ} \mathrm{C}$ with $56.57 \%$ and $65.00 \%$ R.H for the two seasons respectively. After this peak, the population of leafhoppers on cabbage plants tended to decline until the absolutely disappearance in the $1^{\text {st }}$ week of March with at mean temperatures $18.01^{\circ} \mathrm{C}, 20.43^{\circ} \mathrm{C}$ with $57.85 \%$ and $66.14 \%$ R.H in 2002/2003 and 2003/2004 seasons, respectively.

The data obtained show that the population density of E. decedens had only one peak on cabbage plants.

\section{c) Balclutha hortensis (Lindb).}

The total number of $B$. hortensis individuals infesting cabbage plants are illustrated graphically in Figures (5\&6). Both figures illustrated the total number of $B$. hortensis which firstly collected from cabbage plants during two seasons were 18 and 11 individuals $/ 200$ strokes at $1^{\text {st }}$ week of October at a mean temperature at $24.79,26.53^{\circ} \mathrm{C}$ with $58.71 \%, 59.57 \%$ R.H for two seasons, respectively.

One peak was recorded for $B$. hortensis on cabbage plants at the $2^{\text {nd }}$ week of October with a total numbers of 46 and 66 adult/sample at a mean temperature at 
$25.55^{\circ} \mathrm{C}, 24.74{ }^{\circ} \mathrm{C}$ with $61.71 \%, 62.14 \%$ R.H for the two seasons, respectively. Then, the number of $B$. hortensis tended to decline until the hiding at the $1^{\text {st }}$ week of March with a total number of zero and zero individuals/200 strokes at a mean temperature of $18.01^{\circ} \mathrm{C}, 20.43^{\circ} \mathrm{C}$ with $57.85 \%, 66.14 \%$ for the two seasons, respectively.

Results in general concerning the population density of leafhopper species on cabbage plants show clearly that Empoasca. decedens and Balclutha hortensis has only one peak at the $2^{\text {nd }}$ week of November and the $2^{\text {nd }}$ week of October for the two leafhopper species respectively. But E. decipiens had two peaks the first was at the $4^{\text {th }}$ week of October and the second was at $4^{\text {th }}$ week of January during cabbage growing seasons.
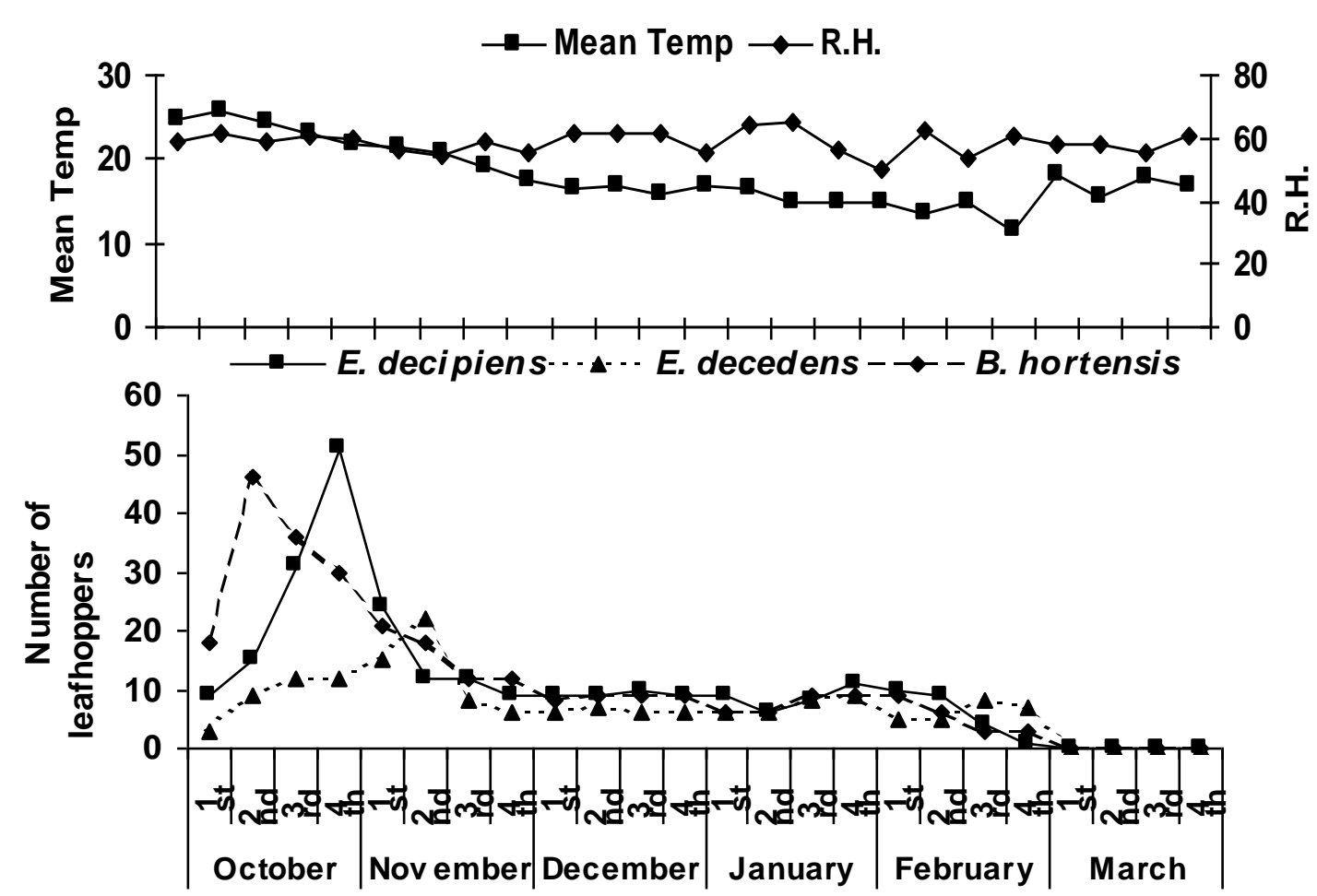

Data of inspactation(w ithin w eek $\$$

Fig. (5): Seasonal abundance of leafhoppers E. decipiens, E. decedens and $B$. hortensis infesting cabbage plants collected by sweeping net at Minia ElKamh district, Sharkia Governorate during 2002/2003 season. 


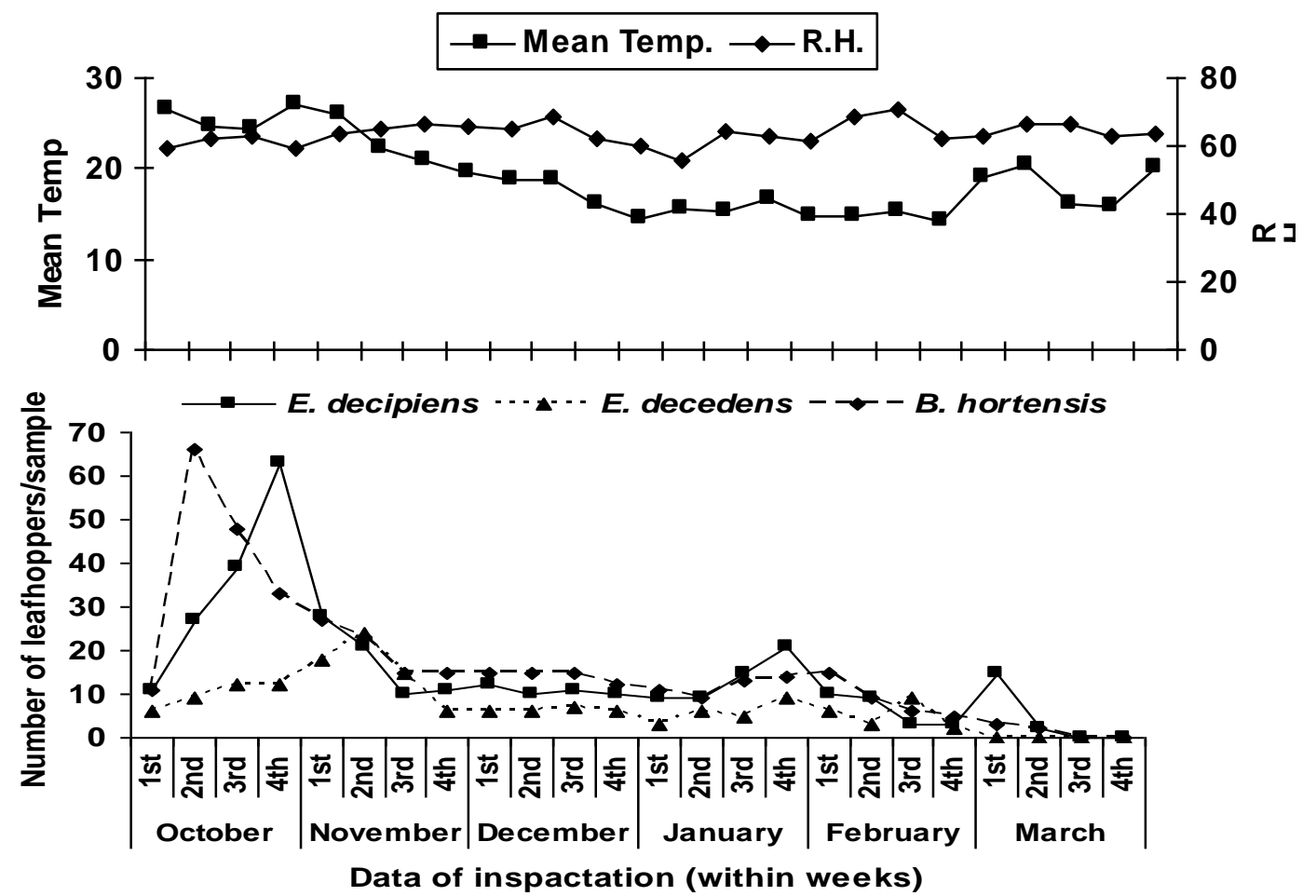

Fig. (6): Seasonal abundance of leafhoppers E. decipiens, E. decedens and B. hortensis infesting cabbage plants collected by sweeping net at Minia El-Kamh district, Sharkia Governorate during 2003/2004 season.

\section{iv) Cauliflower plants}

\section{a) Empoasca decipiens (Paoli).}

Figures $(7 \& 8)$ indicated that the numbers of E. decipiens on cauliflower plants tended to increase until reached its first peak at the end of October with a total numbers of 43 and 47 adults/200 strokes in the two seasons respectively at a mean temperature of $22.92^{\circ} \mathrm{C}, 26.95^{\circ} \mathrm{C}$ with $60.40 \%, 59.60 \%$ R.H for the two seasons of investigation respectively. The second peak was recorded at the last week of January with total numbers of 19 and 15 adults/sample in 2002/2003 and 2003/2004 seasons respectively at a mean temperature of $14.71^{\circ} \mathrm{C}, 14.84^{\circ} \mathrm{C}$ with $56.40 \%, 61.10 \%$ R.H for the two seasons respectively.

It is worth to mentioned that third peak with a low population density was observed only at the $1^{\text {st }}$ week of March in 2003/2004 season with a total numbers of 12 adults/sample at a mean temperatures of $20.43^{\circ} \mathrm{C}$ with $66.14 \%$ R.H. 


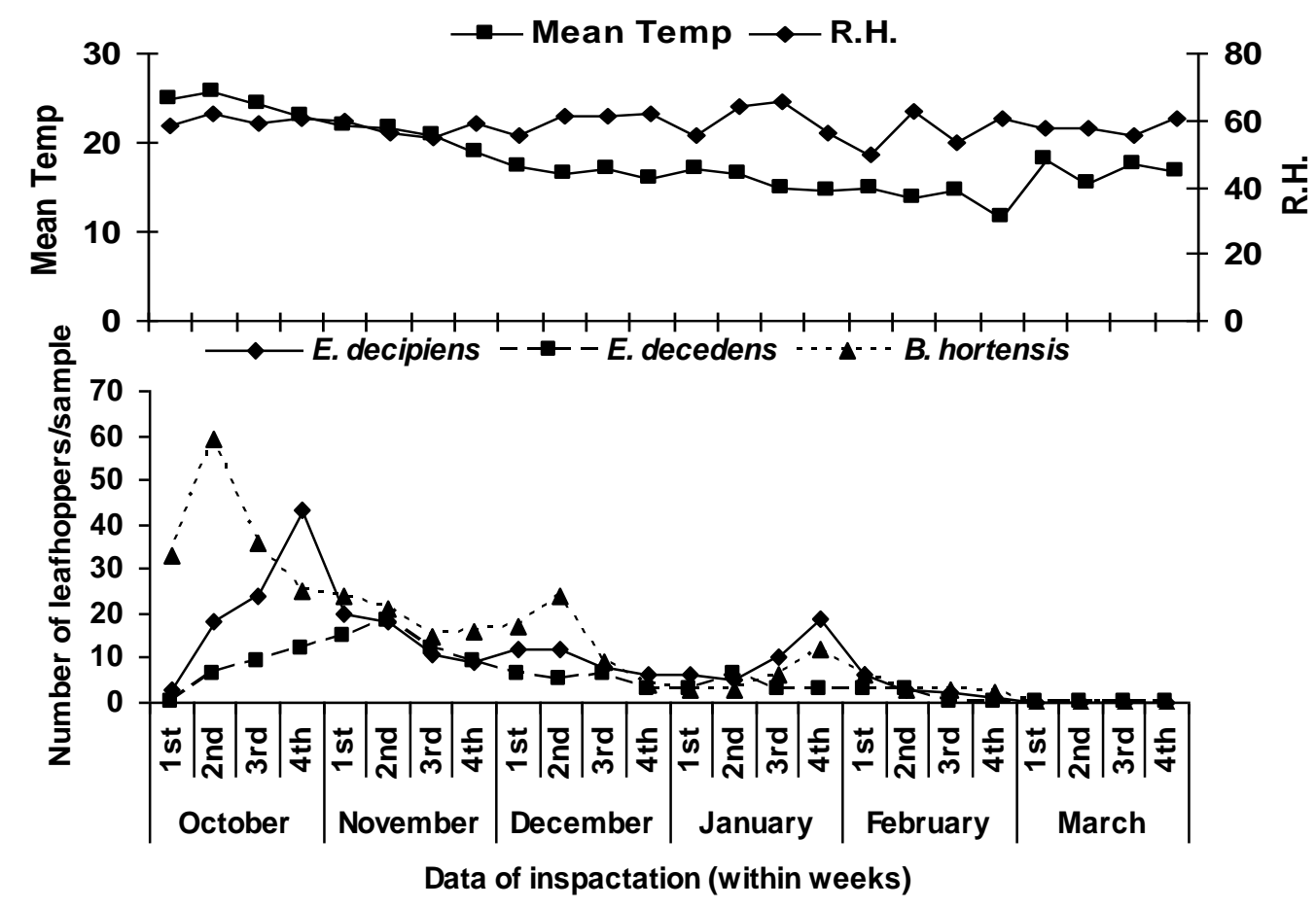

Fig. (7): Seasonal abundance of leafhoppers E. decipiens, E. decedens and B. hortensis infesting cauliflower plants collected by sweeping net at Minia El-Kamh district, Sharkia Governorate during 2002/2003 season.

\section{b) Empoasca decedens (Paoli):}

Data in Figs. (7\&8) showed that only one peak of E. decedens appeared during $2002 / 2003$ and 2003/2004 seasons on cauliflower plants. The peak recorded at the mid November with a total numbers of 18 and 22 adult/sample at $21.55^{\circ} \mathrm{C}$ and $22.27^{\circ} \mathrm{C}$ with $56.57 \%$ and $56.00 \%$ R.H for two seasons respectively.

\section{c) Balclutha hortensis (Lindb):}

In Figs. (7\&8) indicated that the first collection of $B$. hortensis individuals was counted at the $1^{\text {st }}$ week of October (33 and 12 adult/sample) for the two seasons, respectively at $24.79^{\circ} \mathrm{C}, 29.53^{\circ} \mathrm{C}$ with $58.71 \%, 59.57 \%$ R.H. According to the abundance of $B$. hortensis individuals on cauliflower plants, three peaks were recorded, the first one occurred at the mid of October with a total number of 59 and 66 adult/sample $2002 / 2003$ and $2003 / 2004$ seasons, respectively at $25.55^{\circ} \mathrm{C}, 24.74^{\circ} \mathrm{C}$ with $61.71 \%$, $62.14 \%$ R.H for the two seasons, respectively. 


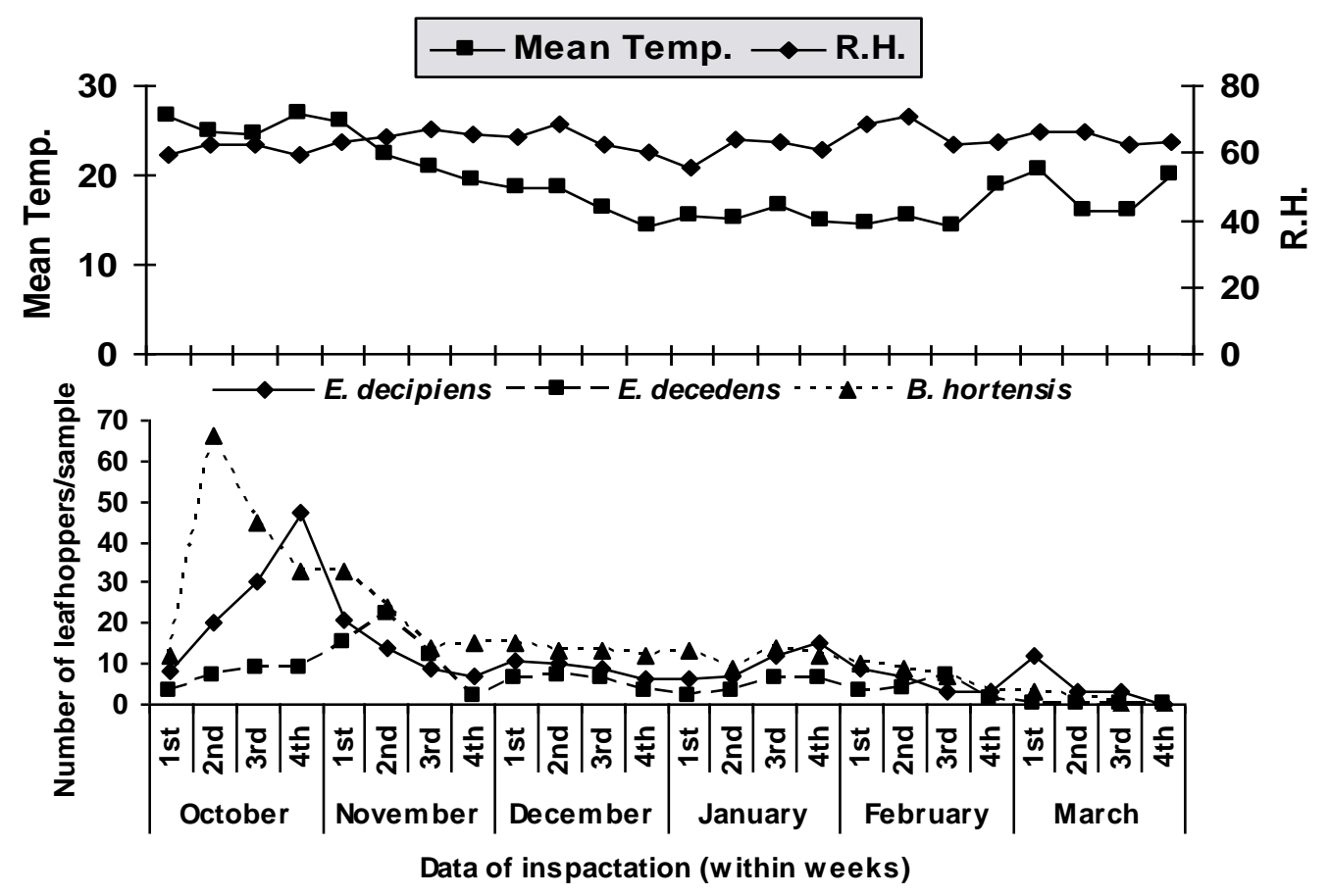

Fig. (8): Seasonal abundance of leafhoppers E. decipiens, E. decedens and B. hortensis on cauliflower plants collected by sweeping net at Minia El-Kamh district, Sharkia Governorate during 2003/2004 season.

The second peak was recorded at the $2^{\text {nd }}$ and $1^{\text {st }}$ week of December with a total number of 24 and 15 adult/sample at $16.57^{\circ} \mathrm{C}, 18.64^{\circ} \mathrm{C}$ with $61.43 \% 65.00 \%$ R.H in $2002 / 2003$ and 2003/2004 seasons, respectively. The third peak was observed at the end of December and at $3^{\text {rd }}$ week of January with a total numbers of 12 and 14 adult/sample at $14.71{ }^{\circ} \mathrm{C}, 16.53^{\circ} \mathrm{C}$ with $56.40 \%$ and $63.14 \%$ R.H in $2002 / 2003$ and 2003/2004 seasons, respectively. After the third peak the number of B. hortensis decreased until the disappearance absolutely at the first and mid of March with a mean temperature of $15.37^{\circ} \mathrm{C}, 15.94^{\circ} \mathrm{C}$ with $57.71 \%, 66.29 \%$ R.H for the two seasons, respectively. Similar results were found by Hegab et al. (1989a,b) and Soliman (1993).

\section{REFERENCES}

El-Blook, M.M. (1976): Survey, Seasonal abundance and host plants of leafhoppers and plant hoppers (Auchenorrhyncha, Homoptera) in Giza region. M.Sc. Thesis, Cairo University.

El-Gendy, M.A. (2002): Studies on certain homopterous insects vectors of plant pathogenic diseases. Ph.D. Thesis, Fac. of Agric., Zagazig Univ. Egypt. 
Hamdi, M.K. (1992): Some ecological aspects on the leafhopper Empoasca decipiens attacking summer vegetable plants in Sharkia Governorate during 1989. Annals of Agric. ,Sci., 37 (2):613-620.

Hamdi, M.K. and Emam A.K. (1994): Diurnal activity of the leafhopper Empoasca decipiens (Paoli) on summer vegetable plants in Egypt. Annals of Agric. Sci. ,39 (1):425-430.

Hegab, A.M.; EL-Zohairy, M.M.; Attia, A. A. and Youssef, A.A.A. (2005): Survey and seasonal abundance of leafhoppers infesting some leguminous crops. Zagazig J. Agric. Res. ,Vol. 32(5): 1649-1662.

Hegab, A.M.; EL-Zohairy, M.M.; Helaly, M.M. (1989a): Survey and seasonal abundance of leafhoppers infesting certain solanaceous vegetable plants in newly reclaimed sandy areas at Salhia district, Egypt. Zagazig J. Agric. Res. ,Vol. 16(2) .

Hegab, A.M.; Helaly, M.M. and Hassanein, S.S.M. (1989b): Survey and seasonal abundance of leafhopper species (Homoptera : cicadellidae) infesting certain cruciferous and cucurbitaceous vegetable plants in newly reclaimed sandy areas at Salhia district, Egypt. Zagazig J. Agric. Res., Vol. 16 (1) .

Hegab, A.M.; Kelany, I.M. and El-Maghraby, M.M. (1987): Survey of leafhoppers and planthoppers infesting maize plants by using three techniques in newly reclaimed sandy areas at Salhia district, Egypt, Minia, J. Agric. Res. \& Dev., 9(2): 945-953.

Helal, A. H., Salem, R.M.; El-Khouly, A.S.; Metwally, M.M. and El-Mezaian, A.B. (1996): Population dynamic of Aphis craccivora Koch and Empoasca spp. on faba bean in relation to associated predators and some climatic factors. Egypt J. Agric. Res., 75 (2): 461-471.

Herakly, F.A. (1974): Preliminary survey of pests infesting solanaceous truck crops in Egypt. Bull. Soc. Ent. Egypt, 58: 133-140.

Soliman, A.S. (1993): Studies on certain pests infesting some cruciferous plants. M. Sc. Thesis Fac. Of Agric. Zagazig. Univ..Egypt. 
حصر ودراسة الوفرة الموسمية لنطاطات الأورلق التي تصيب بعض نباتات العائلة الباذنجانية

\section{والصليبية}

رضا السيد محمد عمر' - على مرسى حجاب' - عبد الرحمن احمد البرى' - مصطفى سعيد هاشمّ

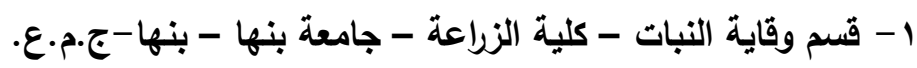

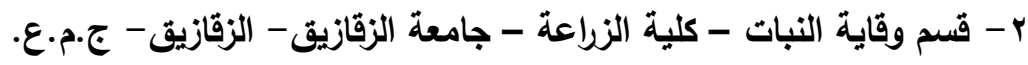

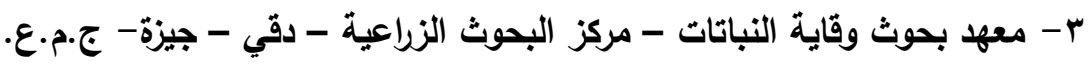

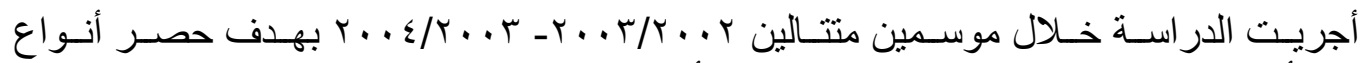

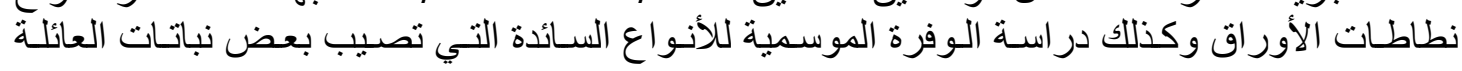

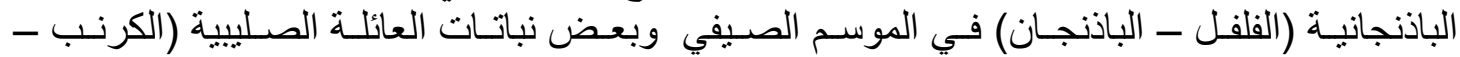

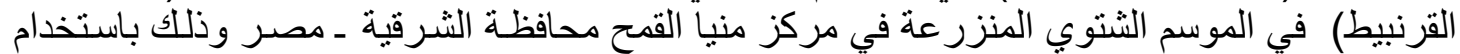

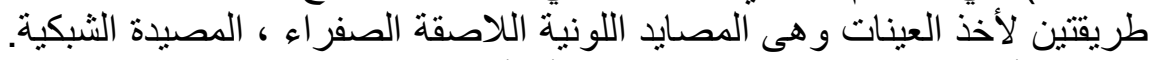
وقد أوضحت النتائج المتحصل عليها أن أنواع النطاطات السائدة والتي تصيب نباتات النات الفلفل هي: Empoasca decipiens(Paoli), Empoasca decedens(Paoli), and Cicadulina china(Ghauri)

على حين أن النوع Circulifer tenellus (Baker) قد وجد بكثافة عدديـة قليلة. بينمـا أنواع نطاطـات الأوراق التي تصسيب نباتـات الباذنجان هي: Empoasca decipiens(Paoli), Empoasca - Cicadulina china(Ghauri)and Empoasca lybica (de Berg) decedens(Paoli), وكان أنو اع نطاطات الأوراق التي تصبي نباتات الكرنب و القرنبيط هي: Empoasca decipiens and Balclutha hortensis (Lindb).

(Paoli), Empoasca decedens (Paoli)

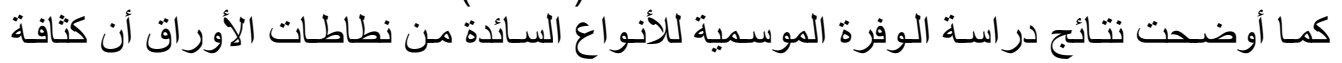
المجموع لحشرة Empoasca decipiens (Paoli) سجلت قمتين علي نباتات الفلفل و الباذنجان النبان

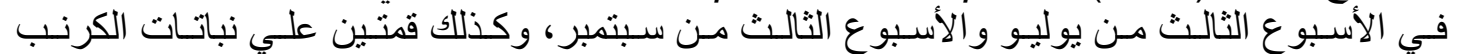

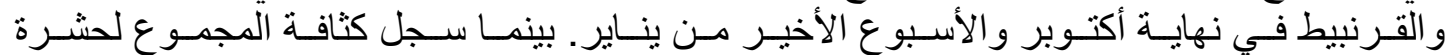
Empoasca decedens (Paoli)

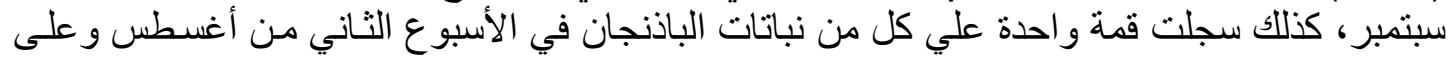

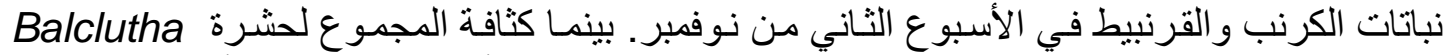
دو hortensis (Lindb)

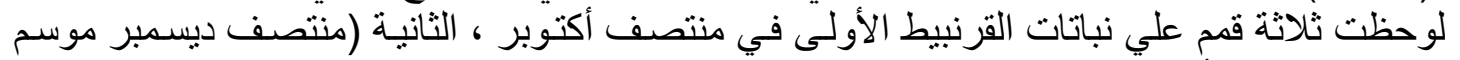

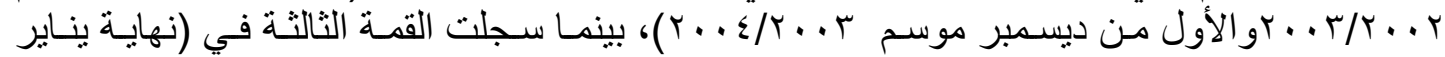

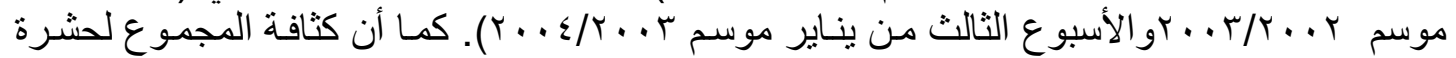
Cicadulina chinai (Ghauri)

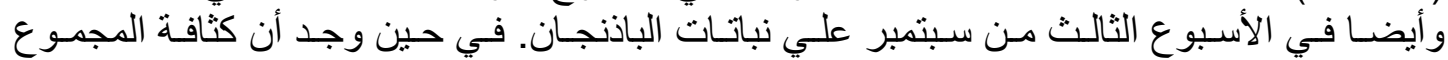
لحشرة Empoasca lybica (de Berg) قد سجلت قمتين الأولى في الأسبوع الأنئ الثالث من يوليو و الثانية في الأسبوع الثالث من سبتمبر علي نباتات الباذنجان. 